\title{
Need Analysis of English For Math Instructional Material
}

\author{
Sitti Nurpahmi ${ }^{1}$, Kamsinah ${ }^{2}$, Nurfajri Ningsih ${ }^{3}$ \\ \{ sitti.nurpahmi@uin-Alauddin.ac.id ${ }^{1}$, kamsinah@uin-Alauddin.ac.id ${ }^{2}$, \\ nurfajri.ningsih@parahikma.ac.id ${ }^{3}$ \} \\ ${ }^{1,2}$ Universitas Islam Negeri Alauddin Makassar, Indonesia \\ ${ }^{3}$ Isntitut Parahikma Indonesia
}

\begin{abstract}
Need analysis is the starting point in designing a course or developing material. It is used to gather information from the population about what they need in learning. This study aims at investigating the needs of English for math instructional material for the mathematics education department at UIN Alauddin Makassar. The design research was descriptive quantitative and qualitative research. The population of the research was 64 students, ten graduates, and two lecturers. Research data were collected by using questionnaire and interview. The questionnaire comprises present situation analysis, target situation analysis, and learning needs. The findings show that 1) students have fair ability in English skills - listening, speaking, reading, writing, vocabulary, and grammar, and pronunciation; 2) students need to learn more in reading than others skills. Vocabulary related to their major, and grammar; 3) students need to learn auditorily and visually through video. Students also need to learn in a small group and work in pairs.
\end{abstract}

Keywords: Math, Mathematics, Instructional Material, English for Math

\section{INTRODUCTION}

In Indonesia, the decree Number 045/U/2002, paragraph 2, article10 specifies that institutional curriculum could include English besides other primary subjects. The National Education Law Number 20 year 2003, paragraph 2, Article 37 stresses that the curriculum at the tertiary level should include English languages, besides Indonesian and local languages. As a subject in an institutional curriculum, English is taught in non- English study programs (such as economics, law, and engineering) across the institution where it is learned to support the key competence of a particular study program. It was subjected to the students who need English for academic studies such as Biology, Physic, and Math.

Data obtained from observation had shown that students of the Mathematics Education Department need English as the key to success in their major disciplines. The students were strongly urged to build up their English Competences as a tool in gaining access to information and materials that did not exist in their language.

The fact has shown that some majors in Tarbiyah and teaching faculty of UIN Alauddin Makassar have been taught English language. However, the lecturer only taught how to make 
simple sentences, and sometimes just give the exercises for them. Lecturer also had not analyzed the learner before providing the material or what the material is relevant to their major. In this case, the lecturer only focuses on teaching general English material. Furthermore, the lecturer used the materials from some resources for the internet or foreign printed book. The lecturer compiled based on the topic that she/he has developed. It is not developed based on need analysis. Therefore, there is a gap between what the lecturer taught and what students need. While [1] point out that need analysis is a starting point in designing course, including material development.

Needs analysis is one of the important stages in the process of language learning materials development, either in English for Specific Purposes (ESP) or general English [2], [3], [4], [5], $[6]$.

Thus, instructional materials based on needs analysis are very important for the students and the lecturers in the teaching and learning process. Without learning material, it might be difficult for the lecturers to improve the effectiveness of the teaching and learning process. In the same cases, the students might be challenging to adjust to the learning, especially if the lecturer teaches the materials quickly and less clearly. Therefore, the materials can be used both the lecturers and students, as an attempt to improve the quality of learning.[7] points out that materials are a key component of the teaching and learning process.

Therefore, to make students easy in catching information from any English literature, so it should facilitate English printed sources that fulfill students' needs. Consequently, it is important to design English for Math material based on integrated need analysis.

\section{METHOD}

Design research was a quantitative and qualitative method. The population of the research was 64 students, 10 graduates, and 2 lecturers. Research data were collected by using questionnaire and interview. The questionnaire comprises present situation analysis, target situation analysis, and learning needs. The questionnaire was validated before using an instrument.

\section{RESULT AND DISCUSSION}

To facilitate students with the instructional material fulfilling their needs, so it should be done need analysis. The students, lecturer, graduates, and experts' perspective of learning English for Math. In this phase, the writer conducted a need analysis procedure to identify present situation analysis, target situation analysis, and learning needs of the students of mathematics Education study program. The data of the needs were collected by giving questionnaires to the respondents of this study, i.e., students, teachers, and graduates. Interview was used to obtain in-depth information on the needs, and to cross-check the data gathered from the questionnaires.

\section{THE OUTLINE OF PRESENT SITUATION ANALYSIS}

This part explains the perceptions of the students, lecturers, employees of learning needs in the ESP classroom for Mathematics Education Department students. It covers general perception of English language used for mathematics education department students, the English language skills which are mostly required, and the learning and teaching activities that are mostly preferred. 


\section{The Outline of Learners' Level of Proficiency}

The result of data analysis of the questionnaire related to the students' level of proficiency can be shown in the following chart:

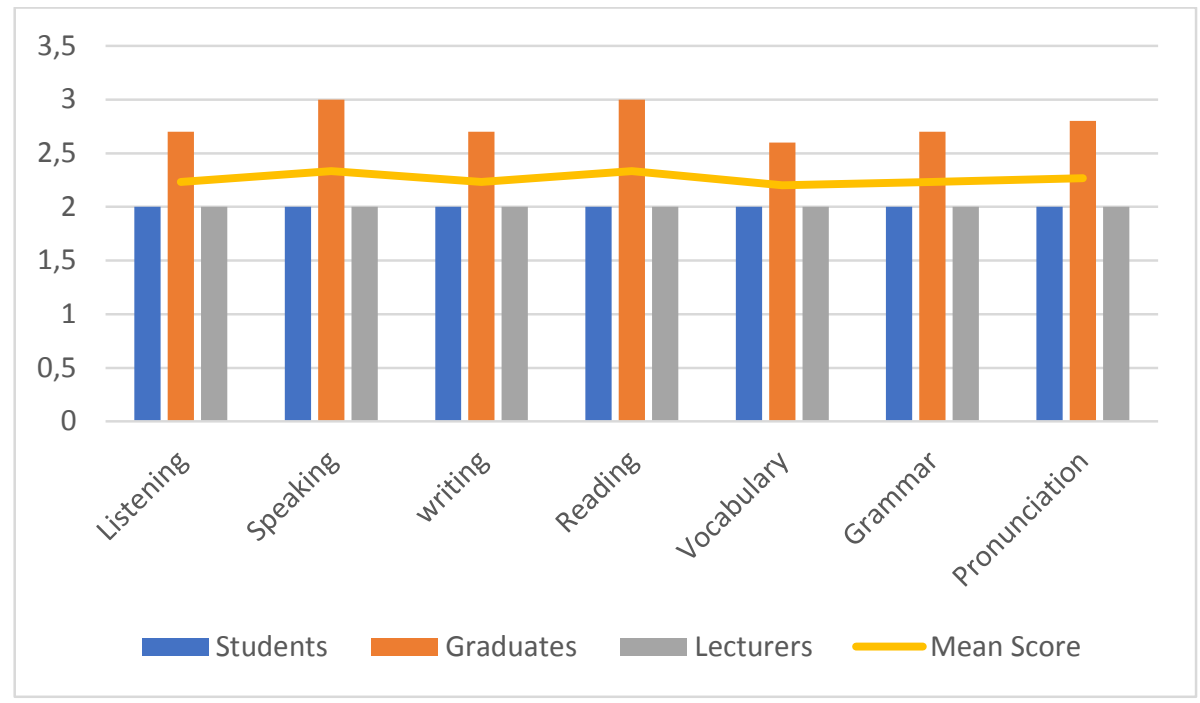

Figure 1. The Outline of the learners' level proficiency

The chart shows that the learners' proficiency level in four skills and three language components are in the fair category. Students, graduates, and lecturers have the same perception of the mathematics English education department students' level of proficiency.

\section{The Outline of The Learners' Learning Difficulties}

The result of data analysis of the questionnaire related to the students' learning difficulties can be shown in the following chart: 


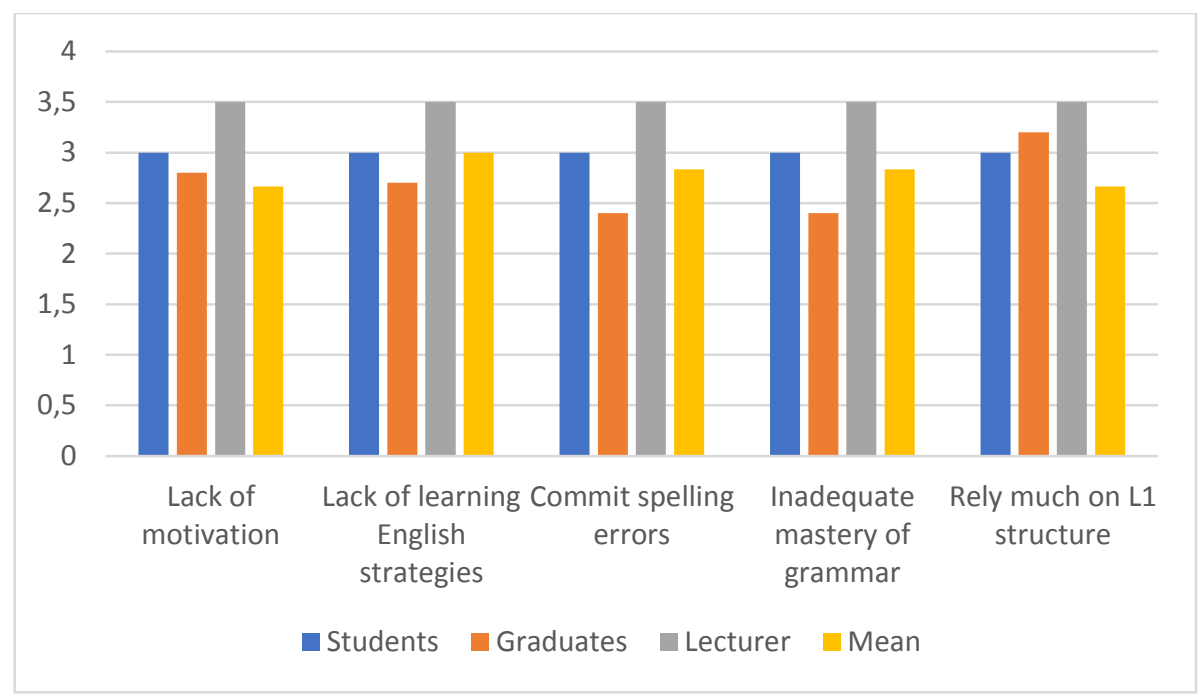

Figure 2. The learners' learning difficulties

The chart above shows that students often get a lack of motivation in learning English, lack of learning strategies, commit spelling errors, inadequate mastery of grammars, and rely much on the first language. The frequency of problems faced by the students is often category. Based on the means score, it shows that the most often problem faced by the student is lack of learning strategies.

\section{The Outline of The Topics}

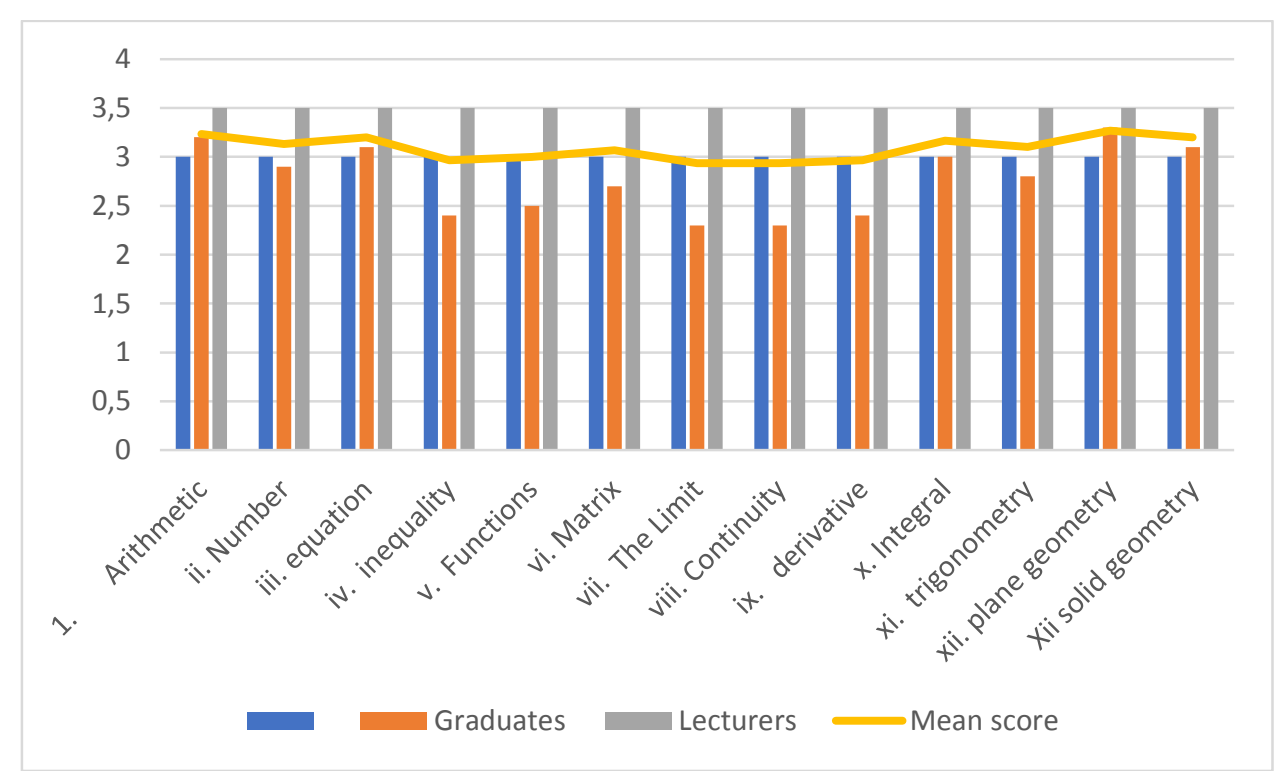

Figure 3. The Outline of the topics 
The chart shows that all topics are categorized as important. The mean score ranges from 2.91 to 3.29 . It is classified as important. While the grammar component that perceived by the students can be seen in the following chart:

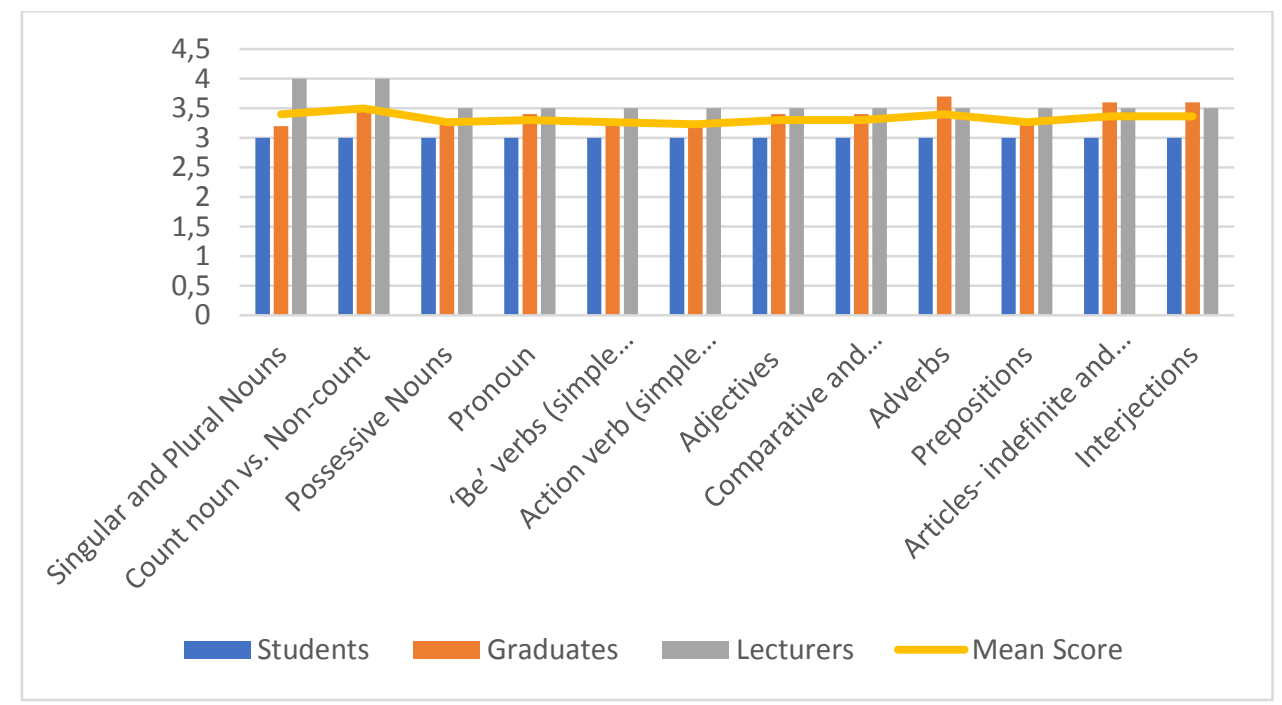

Figure 4. grammar component of students

The chart points out that all the topics in the grammar component are considered important by students, graduates, and lecturer. The mean scores are categorized as important.

\section{TARGET SITUATION ANALYSIS}

The Outline of The Important of Language Component and Language Skills In Learning English For Mathematics

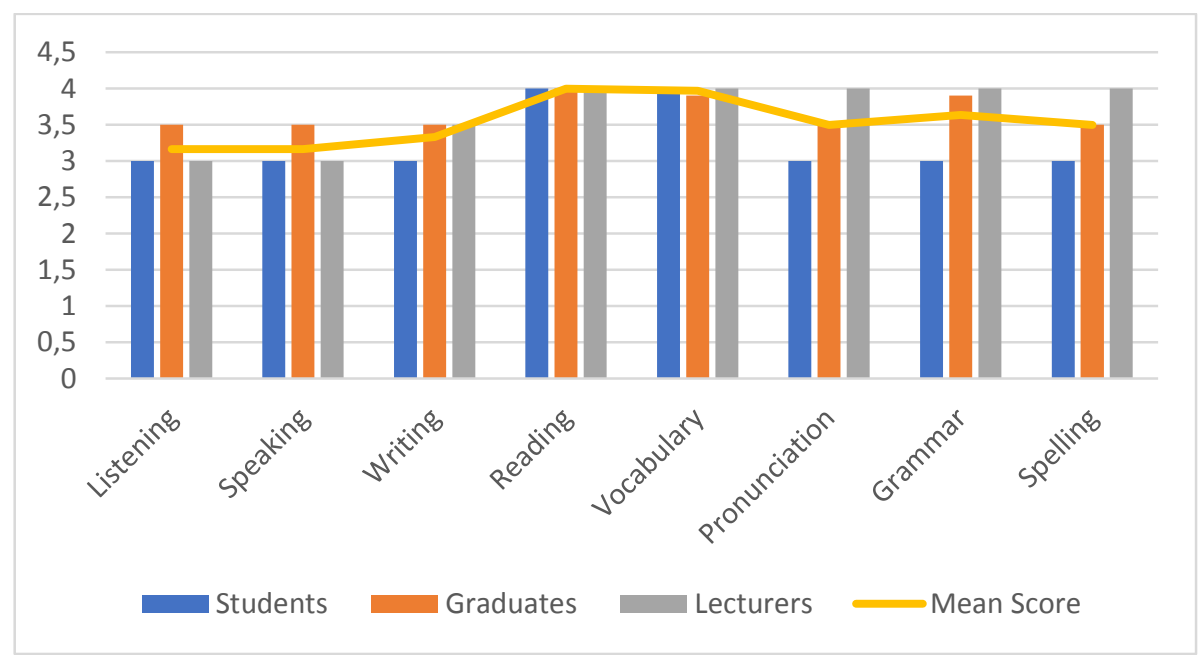

Figure 5. The importance of Language skills and Language component 
The chart illustrates that the mean score for each element is in important categorization. The most important skills among skills were reading, followed by writing, speaking, and listening. While the most important language component was vocabulary, followed by grammar, pronunciation, and spelling. It means that all of the skills and language components should be included in instructional material.

\section{Writing Micro Skills}

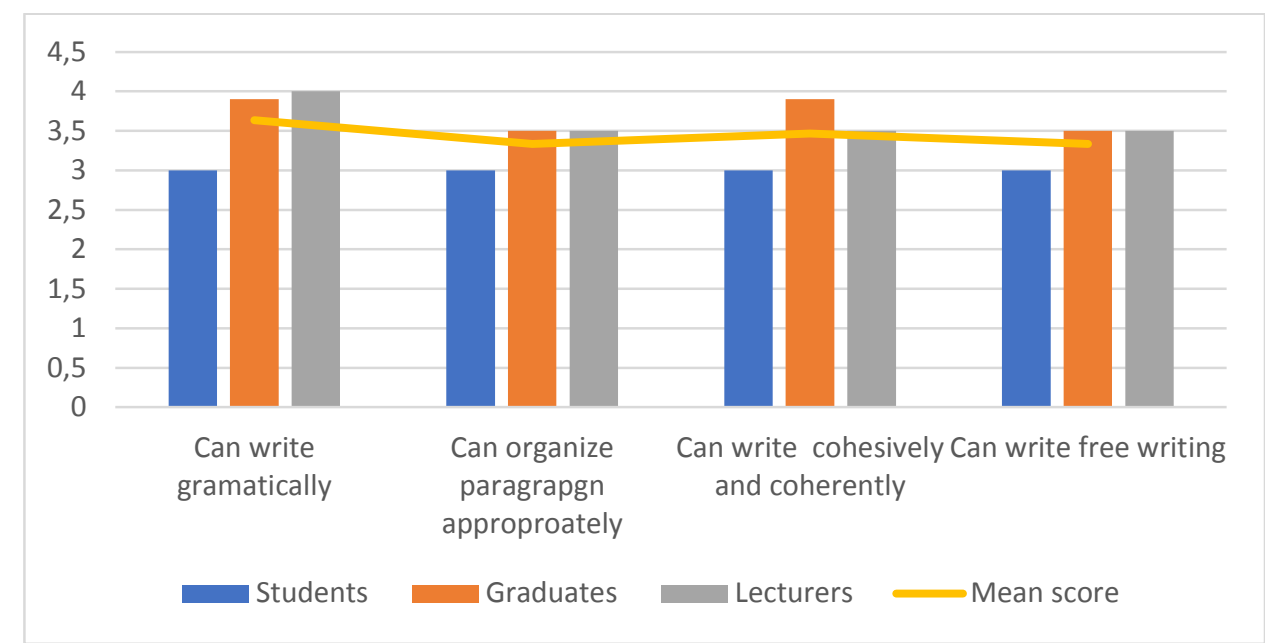

Figure 6. Micro skills of writing

The chart describes the micro-skills that is most important in writing. Writing grammatically is considered as most important micro-skills. It is followed by writing cohesively and coherently, organizing paragraphs, writing free writing. 


\section{Speaking Micro Skills}

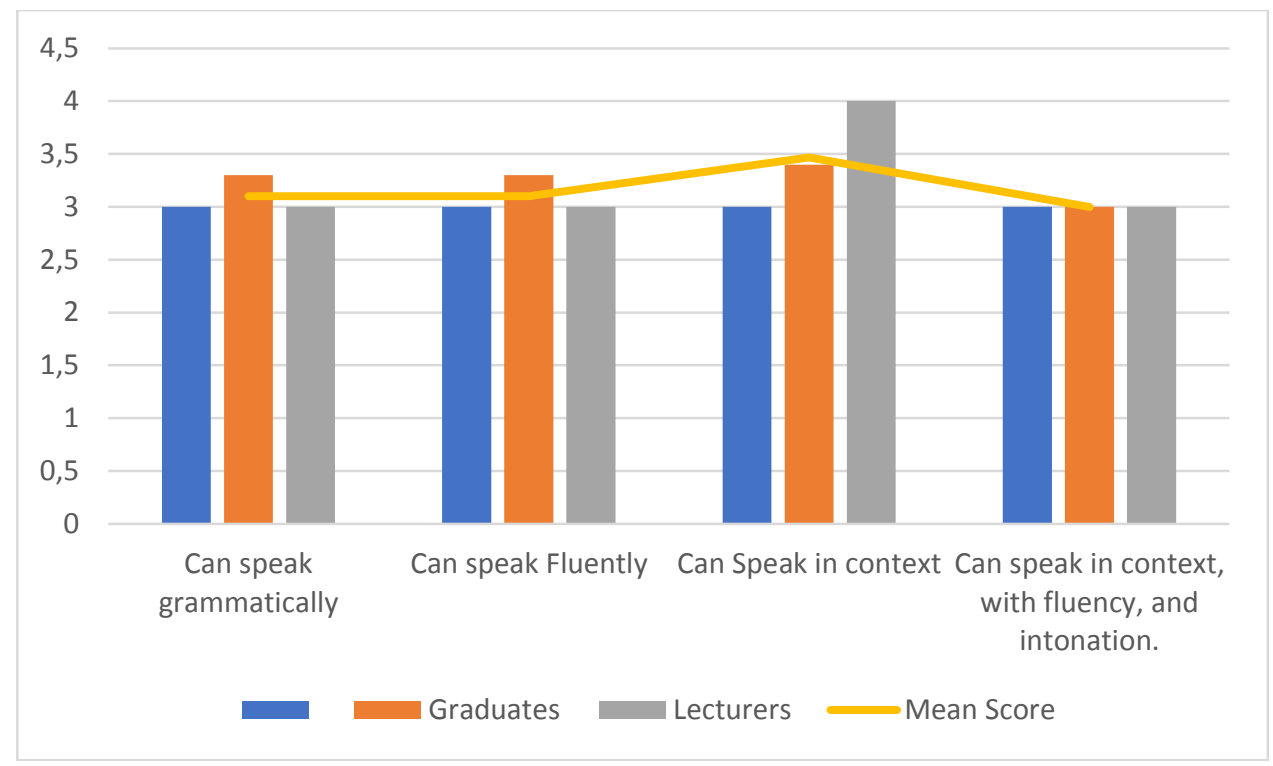

Figure 7. Micro Skills of Speaking

The chart describes the micro-skills that the students think most important. Speaking in context is considered the most important micro-skills followed by speaking grammatically, speaking fluently, and speaking in context, fluent, and appropriate intonation.

\section{Listening Micro Skills}

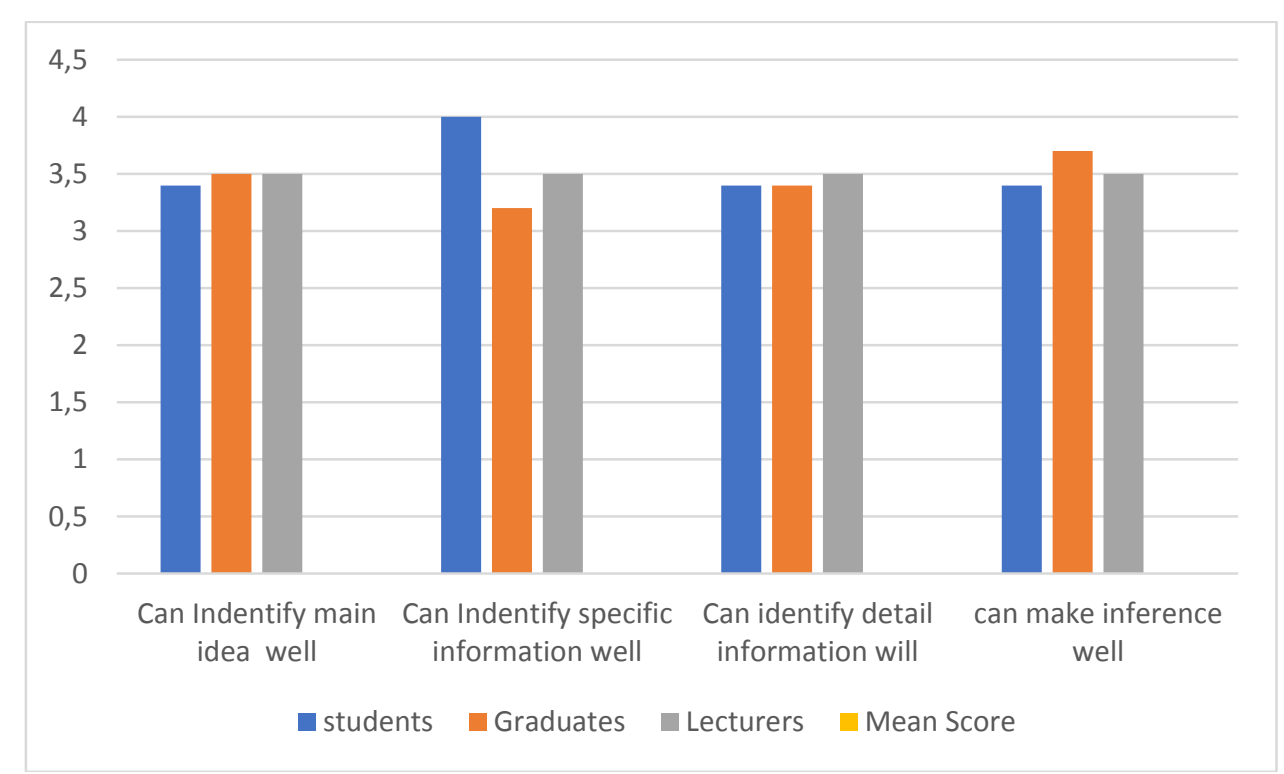

Figure 8. Micro Skills of Listening 
The chart describes that all micro-skills are in important categorization. It means that all the components should be in instructional material with the same percentage.

\section{Reading}

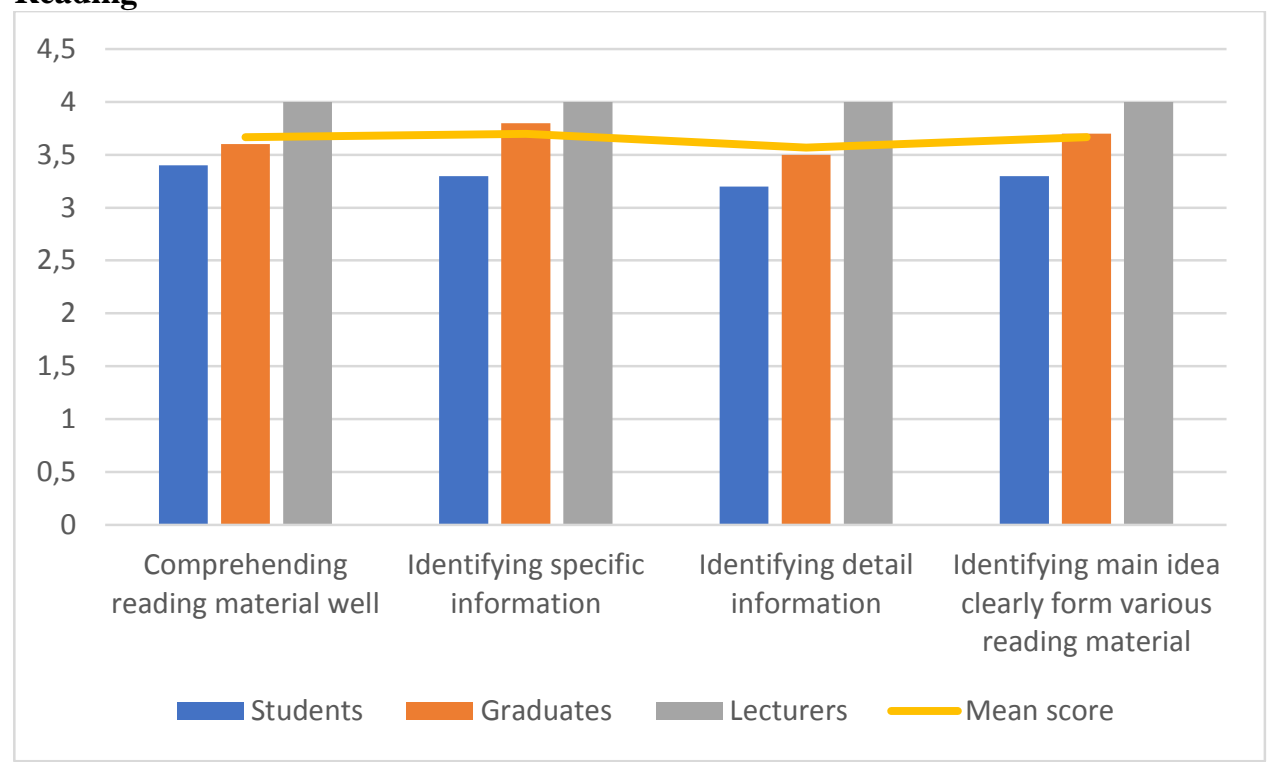

Figure 8. Micro skills of Reading

The chart describes that all micro-skills is reading are in very important categorization. It implies that all the components should be included in instructional material.

\section{The Outline of The Purposes of Learning English The Topic Important For The Students}

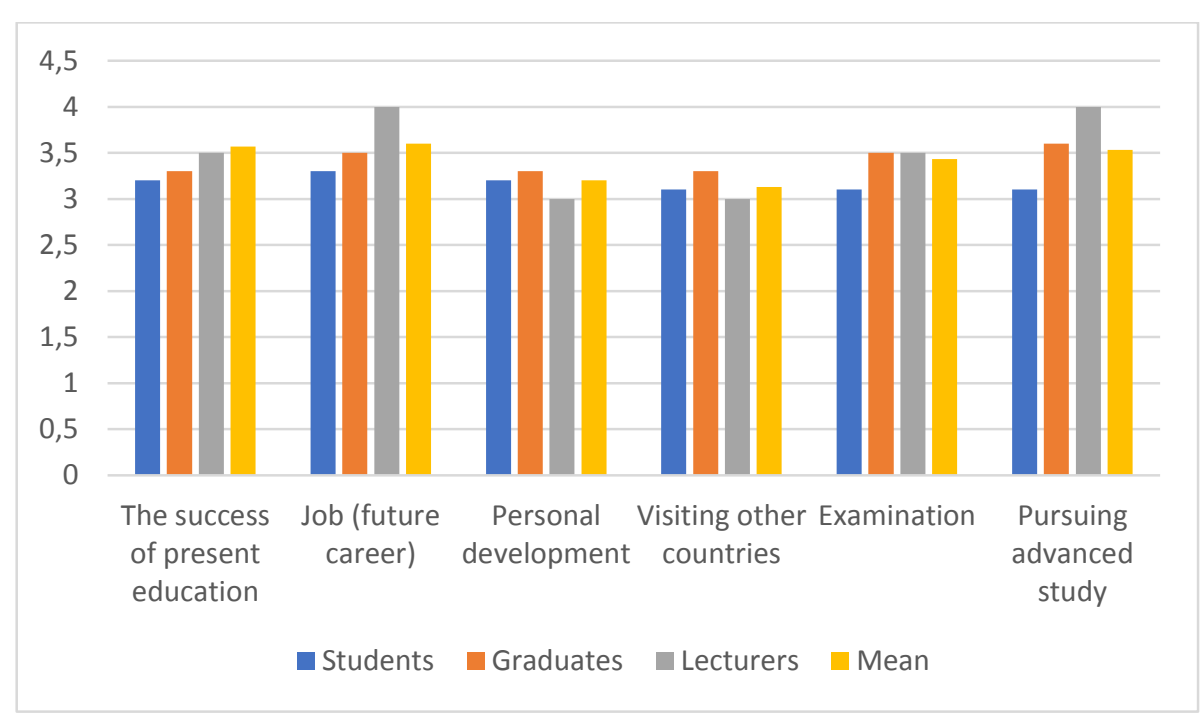

Figure 9. The outline of learning purposes 
The chart shows that the English language is recognized to be at the important level (between 3. 1 and 4) as a tool to pursuing advanced study followed by as tool of succeeding in present education and getting the examination. Personal development and visiting other counties are also in important categorization, comes after the previous component.

\section{LEARNING NEEDS}

\section{The Outline of Student's Learning Preference and Styles}

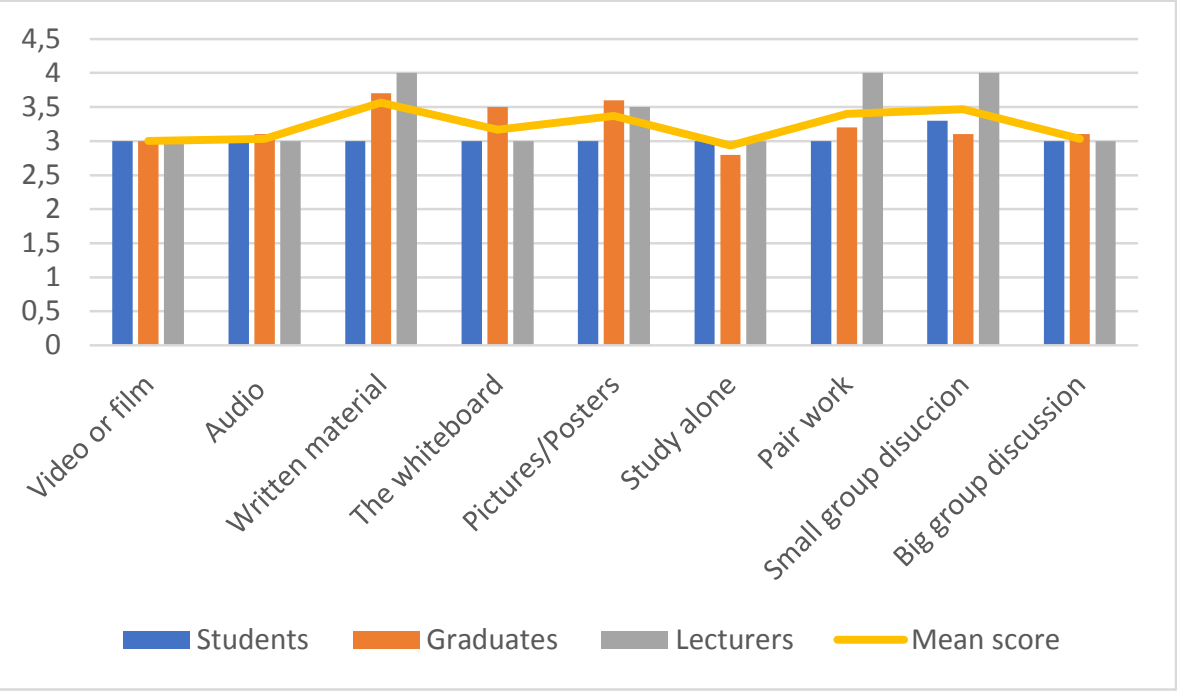

Figure 10. The outline of students' preferences and styles

The chart shows that students like learning using written material and pictures more than audio, video or film, and the whiteboard. The students also like studying in small group discussions more than big group discussion. The students also prefer pair work than studying alone.

\section{DISCUSSION}

Therefore, to make students easy in catching information from any English literature, so it should facilitate English printed sources that fulfill students' needs. Therefore, it is important to design English for Math material based on integrated need analysis.

Based on the data analysis, it can be inferred the need inventory of English for Math Instructional Material as follows:

Table 1. Students‘ Learning ability

\begin{tabular}{cc}
\hline Learning ability & inference \\
\hline Fair in listening & Students need to learn all the skills and \\
Fair in reading & component because all categorization is in \\
Fair in writing & fair. \\
Fair in speaking & \\
Fair grammar & \\
Fair in vocabulary & \\
Fair in pronunciation & \\
\hline
\end{tabular}


Table 2. Students; learning Problem

\begin{tabular}{|c|c|c|c|}
\hline \multicolumn{2}{|r|}{ Learning Problems } & \multicolumn{2}{|l|}{ Explanation } \\
\hline 1 & Lack of learning English strategies & \multicolumn{2}{|c|}{$\begin{array}{c}\text { Facilitate instructional } \\
\text { material with strategies to } \\
\text { learn it }\end{array}$} \\
\hline 2 & Commit spelling errors & \multicolumn{2}{|c|}{ More exercises in spelling } \\
\hline 3 & Inadequate mastery of grammar & \multicolumn{2}{|c|}{ More exercises in grammar } \\
\hline 4 & Lack of motivation & \multicolumn{2}{|c|}{$\begin{array}{l}\text { Facilitate material that can } \\
\text { motivate students }\end{array}$} \\
\hline 5 & Rely much on L1 structure & \multicolumn{2}{|c|}{$\begin{array}{l}\text { Give more exercises on target } \\
\text { language structure }\end{array}$} \\
\hline \multicolumn{4}{|c|}{ Table 3. The Outline of The Topics } \\
\hline Top & Mean Score & Grammar Component & $\begin{array}{l}\text { Mean } \\
\text { Score }\end{array}$ \\
\hline Plan & 3.26666667 & Count noun vs. Non-count & 3.5 \\
\hline Aritl & 3.23333333 & Singular and Plural Nouns & 3.4 \\
\hline equa & 3.2 & Adverbs & 3.4 \\
\hline Soli & geometry & $\begin{array}{l}\text { Articles- indefinite and } \\
\text { Definite }\end{array}$ & 3.3666667 \\
\hline Inte & 3.16666667 & Interjections & 3.3666667 \\
\hline Num & 3.13333333 & Pronoun & 3.3 \\
\hline trig & lometry & Adjectives & 3.3 \\
\hline Matı & 3.06666667 & Comparative and Superlative & 3.3 \\
\hline Func & ons & Possessive Nouns & 3.2666667 \\
\hline Ineq & 2.96666667 & 'Be’ verbs (simple present 1) & 3.2666667 \\
\hline Deri & 2.96666667 & Prepositions & 3.2666667 \\
\hline The & 2.93333333 & Action verb (simple present 2) & 3.2333333 \\
\hline Con & 2.93333333 & & \\
\hline
\end{tabular}




\section{Target Situation Analysis}

Table 4. The importance of language skills and language component

\begin{tabular}{lr}
\hline $\begin{array}{l}\text { Language skills } \\
\text { and Language } \\
\text { Component }\end{array}$ & $\begin{array}{l}\text { Mean } \\
\text { Score }\end{array}$ \\
\hline Reading & 4 \\
\hline Vocabulary & 3.9666667 \\
\hline Grammar & 3.6333333 \\
\hline Pronunciation & 3.5 \\
\hline Spelling & 3.5 \\
\hline Writing & 3.3333333 \\
\hline Listening & 3.1666667 \\
\hline Speaking & 3.1666667 \\
\hline
\end{tabular}

Table 5. The Micro Skills of English Skills

\begin{tabular}{|c|c|c|c|c|c|c|c|}
\hline Listening & $\begin{array}{l}\text { Mean } \\
\text { Score }\end{array}$ & Speaking & $\begin{array}{l}\text { Mean } \\
\text { Score }\end{array}$ & $\begin{array}{l}\text { Writing } \\
\text { Skill }\end{array}$ & $\begin{array}{l}\text { Mean } \\
\text { score }\end{array}$ & Reading & $\begin{array}{l}\text { Mean } \\
\text { score }\end{array}$ \\
\hline $\begin{array}{l}\text { Can } \\
\text { Identify } \\
\text { specific } \\
\text { informatio } \\
\text { n well }\end{array}$ & 3.567 & $\begin{array}{l}\text { Can Speak } \\
\text { in context }\end{array}$ & 3.47 & $\begin{array}{l}\text { Can write } \\
\text { grammaticall } \\
\text { y }\end{array}$ & 3.63 & $\begin{array}{l}\text { Identifying } \\
\text { specific } \\
\text { information }\end{array}$ & 3.7 \\
\hline $\begin{array}{l}\text { can make } \\
\text { inference } \\
\text { well }\end{array}$ & 3.533 & $\begin{array}{l}\text { Can speak } \\
\text { grammatical } \\
\text { ly }\end{array}$ & 3.1 & $\begin{array}{l}\text { Can write } \\
\text { cohesively } \\
\text { and } \\
\text { coherence }\end{array}$ & 3.47 & $\begin{array}{l}\text { Comprehending } \\
\text { reading } \\
\text { material well }\end{array}$ & 3.67 \\
\hline $\begin{array}{l}\text { Can } \\
\text { Identify } \\
\text { main idea } \\
\text { well }\end{array}$ & 3.467 & $\begin{array}{l}\text { Can speak } \\
\text { Fluently }\end{array}$ & 3.1 & $\begin{array}{l}\text { Can organize } \\
\text { paragraph } \\
\text { appropriately }\end{array}$ & 3.33 & $\begin{array}{l}\text { Identifying } \\
\text { main idea } \\
\text { clearly form } \\
\text { various reading } \\
\text { material }\end{array}$ & 3.67 \\
\hline $\begin{array}{l}\text { Can } \\
\text { identify } \\
\text { detail } \\
\text { informatio } \\
\text { n will }\end{array}$ & 3.43 & $\begin{array}{l}\text { Can speak } \\
\text { in context, } \\
\text { with } \\
\text { fluency, and } \\
\text { intonation. }\end{array}$ & 3 & $\begin{array}{l}\text { Can write } \\
\text { free writing }\end{array}$ & 3.33 & $\begin{array}{l}\text { Identifying } \\
\text { detail } \\
\text { information }\end{array}$ & 3.57 \\
\hline \multicolumn{2}{|c|}{$\begin{array}{l}0-1.50=\text { Not } \\
\text { important }\end{array}$} & \multicolumn{2}{|c|}{$\begin{array}{l}1.51-2.50=\text { Less } \\
\text { important }\end{array}$} & \multicolumn{2}{|l|}{$\begin{array}{l}2.51-3.50= \\
\text { Important; }\end{array}$} & \multicolumn{2}{|l|}{$\begin{array}{l}3.51-4.00=\text { Very } \\
\text { important }\end{array}$} \\
\hline
\end{tabular}


Table 6. Students' Purposes in Learning English

\begin{tabular}{cc}
\hline Purpose & Mean score \\
\hline Job (future career) & 3.6 \\
\hline $\begin{array}{c}\text { The success of present } \\
\text { education }\end{array}$ & 3.57 \\
\hline Pursuing advanced study & 3.53 \\
\hline Examination & 3.43 \\
\hline Personal development & 3.2 \\
\hline Visiting other countries & 3.13 \\
\hline
\end{tabular}

\section{Learning Needs ${ }^{6}$ of The Students}

Table 7. Learning preferences

\begin{tabular}{cc}
\hline Learning Preference & $\begin{array}{c}\text { Mean } \\
\text { score }\end{array}$ \\
\hline Written material & 3.5666667 \\
\hline mall group discussion & 3.4666667 \\
\hline Pair work & 3.4 \\
\hline Pictures/Posters & 3.3666667 \\
\hline The whiteboard & 3.1666667 \\
\hline Audio & 3.0333333 \\
\hline Big group discussion & 3.0333333 \\
\hline Video or film & 3 \\
\hline Study alone & 2.9333333 \\
\hline
\end{tabular}

The students of mathematics education department have fair ablity in English. This finding was supported by the students statement as follows:

Saya tidak mampu berbahasa Inggris. Saya hanya mengetahui sedikit, sedikit kosakata, sedikit grammar, sedikit kemampuan mengucapkan, mendengarkan, menulis, apalagi bercakap. Tapi diantara keterampilan berbahasa yang lain, reading lebih mudah dan lebih dibutuhkan (students 7, April 2019).

I cannot speak English. I know just a little, a little vocabulary, grammar, pronunciation, listening, writing, even speaking. However, among language skills, reading is easier dan needed more.

Another students states that:

Menurut saya, yang sangat kami butuhkan sebagai mahasiswa jurusan Pendidikan Bahasa Matematika adalah Bahasa Inggis yang bisa membantu kami untuk mengakses sumber-sumber informasi dari internet yang kebanyakan berbahasa Inggris (students 5, Interview, April, 2019). 
In my point of view, As a student of the Mathematics education department, we need English that can we need to access information from the internet, which is most of it written in English.

The students reckon that English is very important as a pre-requisite for success in learning. Hence, for success in their field, the issue of internalizing the English language needs to be addressed jointly by them.

Bahasa Inggris tentu sangat penting untuk dipelajari karena sekarang sudah era global dimana bahasa inggris dibutuhkan di semua area baik di dunia akademik maupun ditempat kerja nantinya. Di dunia akademik sekarang ini,, banyak sekali materi-materi yang berkiatan dengan jjurusan matematika yang berbahasa Inggris. Kalau tidak mampu berbahasa Inggris, akan sangat sulit buat kami untuk mampu mengaksesnya.

(Interview, April 13, 2019)

A quite similar statement was also found in the interview which was addressed by another student who stated that: Student 32)

Mempelajari Bahasa Inggris bukan lagi pilihan tetapi kebutuhan. Era sekarang ini menuntut perguruan tinggi untuk mampu berkompetesi secara global dan untuk bias berkompetesi secara global, maka Bahasa Inggris adalah syaratnya. Dengan demikian kita harus belajar Bahasa Inggris tidak hanya di ruang-ruang kelas tapi juga di luar kelas.

Learning English is not only a choice but a need of the learners. This era requires the university to be able to compete globally, and to be able to compete globally, English is a requirement.

\section{CONCLUSION}

Based on the finding and discussion, it can be concluded that

1. Students have the fair ability in English skills - listening, speaking, reading, writing, vocabulary, and grammar, and pronunciation, therefore, material developed should be in line with the level of the student's level of proficiency.

2. All components of language and language skills are categorized as important. Therefore, they need to accommodate instructional material.

3. Students need to learn more in reading than other skills, vocabulary related to their major, and grammar.

4. Students prefer to learn from written material, pictures rather than the prow whiteboard. The students prefer to learn in pairs of work and small groups.

\section{Acknowledgments}

The study was conducted with the support of the students of mathematics Education Department academic year 2018/2019, the lecturers, and graduates. For every support, help., the writers address a big thanks.

\section{References}

[1] T. Hutchinson and A. Waters, English for Specific Purposes: A Learning-centred Approach Excerpt More information. .

[2] J. D. Brown, The elements of language curriculum : a systematic approach to program 
development. Heinle \& Heinle, 1995.

[3] T. Dudley-Evans and M. J. St. John, Developments in English for Academic Purposes: a multi-disciplinary approach. Cambridge, UK: Cambridge University Press, 2006.

[4] M. Ellis and C. Johnson, Teaching business English. Oxford University Press, 1994.

[5] F. Chambers, "A re-evaluation of needs analysis in ESP," ESP J., vol. 1, no. 1, pp. 2533, 1980.

[6] S. Nurpahmi;, "English for specific purposes : integrated approach," 2014.

[7] C. Alan, Evaluating and Selecting EFL Teaching Materials. Great Britain: Biddles Ltd., 1984. 